Quality : Jurnal Kesehatan

Volume 15, Nomor 2 Tahun 2021

pISSN : 1978-4325, eISSN : 2655-2434, DOI: 10.36082/qjk.v15i2200

\title{
FAKTOR BERHUBUNGAN DENGAN PEMILIHAN METODE KONTRASEPSI DI WILAYAH PUSKESMAS JALAN EMAS KABUPATEN TANGERANG PROVINSI BANTEN
}

\begin{tabular}{|c|c|}
\hline Info Artikel & Abstrak \\
\hline $\begin{array}{l}\text { Genesis Naskah: } \\
\text { Submitted: } 22-2-2021 \\
\text { Revised: } 8-11-2021 \\
\text { Accepted: } 25-11-2021\end{array}$ & $\begin{array}{l}\text { Berdasarkan Profil Kesehatan Kabupaten Tangerang Tahun } 2018 \text {, menurut jenis kontrasepsi di } \\
\text { Puskesmas Jalan Emas persentase peserta KB aktif MKJP adalah sebesar } 14,6 \% \text { dan Non MKJP } \\
\text { sebesar } 85,4 \% \text {. Hal ini berhubungan dengan kenaikan jumlah total kelahiran Kabupaten Tangerang } \\
\text { pada tahun } 2018 \text { menjadi } 74.987 \text { kelahiran. Wanita akseptor KB sangat berperan dalam pemilihan } \\
\text { metode kontrasepsi yang sedang digunakan. Penelitian ini bertujuan untuk menganalisis faktor- } \\
\text { faktor yang berhubungan dengan pemilihan metode kontrasepsi pada wanita akseptor KB di } \\
\text { wilayah kerja Puskesmas Jalan Emas. Metode yang digunakan adalah cross sectional. Penelitian } \\
\text { ini dilakukan pada bulan Januari hingga Februari } 2021 \text { dengan jumlah sampel sebanyak } 330 \text { wanita } \\
\text { akseptor KB di wilayah kerja Puskesmas Jalan Emas. Teknik Sampling yang digunakan adalah } \\
\text { cluster sampling dan proportionate random sampling. Hasil uji statistik dengan chi square } \\
\text { diperoleh hasil adanya hubungan signifikan antara tingkat pendidikan dasar }(p \text {-value }=0,000 \text { ), } \\
\text { pengetahuan kurang ( } p \text {-value }=0,034) \text {, kelengkapan pelayanan KB ( } p \text {-value }=0,001) \text {, paparan } \\
\text { informasi KB ( } p \text {-value }=0,036) \text {, dan akses pelayanan KB ( } p \text {-value }=0,022) \text { terhadap pemilihan } \\
\text { metode kontrasepsi pada wanita akseptor KB. Diharapkan wanita akseptor KB dapat meningkatkan } \\
\text { wawasan dan informasi yang tepat mengenai manfaat dan efektifitas penggunaan kontrasepsi } \\
\text { sehingga dapat meningkatkan partisipasi penggunaan metode kontrasepsi jangka panjang atau } \\
\text { MKJP. }\end{array}$ \\
\hline
\end{tabular}

FACTORS ASSOCIATED SELECTION OF CONTRACEPTION METHODS IN THE WORK AREA JALAN EMAS COMMUNITY HEALTH CENTER

Keywords:
Risk factor, contraceptive
methods

Korespondensi Penulis:

Fanira Cahyaningtyas

Program Studi Kesehatan Masyarakat, Universitas Pembangunan Nasional Veteran Jakarta,

Email: faniracahyaningtyas@upnvj.ac.id

(C) Poltekkes Kemenkes Jakarta I

Jl. Wijaya Kusuma No. 47-48 Cilandak Jakarta Selatan, Indonesia

email: jurnalquality@poltekkesjakarta1.ac.id

\begin{abstract}
Tangerang District Health in 2018 noted that the contraceptive method at Jalan Emas Community Health Center with active Long-term contraception method participants was $14.6 \%$ and Non Longterm contraception method was $85.4 \%$. This is related to the increase the total number of births in Tangerang Regency in 2018 up to 74.987 births. Female acceptors are very important about choosing the contraceptive methods. The purpose of this study was to analyze factors associated with the choice of contraceptive methods among female acceptors in the work area of the Jalan Emas Community Health Center. The research design used in this study was cross sectional. The sampling technique used was cluster sampling and proportionate random sampling. The results of statistical tests with chi square showed that there was a significant relationship between the level of basic education ( $p$ value $=0,000$ ), lack of knowledge ( $p$-value=0,034), completeness of family planning services ( $\mathrm{p}$-value $=0,001$ ), exposure to family planning information (pvalue $=0,036$ ), and access to family planning services $(\mathrm{p}$-value=0,022) on the choice of contraceptive methods among female acceptors. It is hoped that female acceptors can increase insight and correct information about benefits and effectiveness of contraceptive use to increase female acceptors participation in use of long-term contraceptive methods.
\end{abstract} ISSN 2655-2434

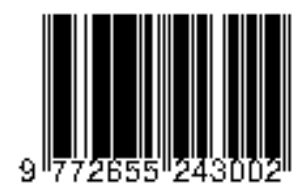




\section{Pendahuluan}

Kebijakan pemerintah dalam mengendalikan angka kelahiran adalah dengan menjalankan program Keluarga Berencana (KB) sejak tahun 1970 yang bertujuan membantu masyarakat agar mampu merencanakan jumlah anak dalam keluarga dengan hasil akhir mengendalikan angka penduduk Indonesia (BKKBN, 2018). Keluarga Berencana merupakan tindakan membantu individu atau pasangan mendapat pandangan tertentu, menghindari kelahiran yang tidak diinginkan, mendapatkan kelahiran yang diinginkan, mengatur jarak antar kehamilan, mengontrol waktu saat kehamilan dalam hubungan suami istri dan menentukan jumlah anak (BKKBN, 2017). Faktor utama pengaturan kehamilan program $\mathrm{KB}$ adalah penggunaan alat kontrasepsi yang tepat. Alat kontrasepsi tersebut dapat dibagi menjadi Metode Kontrasepsi Jangka Panjang (MKJP) yang terdiri dari IUD dan implan dan yang bukan termasuk kontrasepsi MKJP adalah kondom, pil, dan suntik KB.

Riset kesehatan dasar (Riskesdas) tahun 2018 mencatat bahwa besar proporsi penggunaan cara KB pada wanita berusia 10-54 tahun setelah wanita terakhir melahirkan adalah jenis IUD sebesar 4,9, suntikan 3 bulan sebesar 53,8, suntikan 1 bulan sebesar 4,9, implan sebesar 3,5, pil sebesar 8,3 dan kondom sebesar 1,2 (Kementerian Kesehatan RI, 2018). Provinsi Banten merupakan provinsi yang belum mencapai target jumlah pengguna KB MKJP sesuai Renstra BKKBN. Cakupan peserta KB MKJP aktif Provinsi Banten tahun 2018 hanya sebesar 18,5\% sedangkan Non MKJP sebesar 81,5\% (Dinas Kesehatan Provinsi Banten, 2019). Dari semua Pasangan Usia Subur (PUS) di Provinsi Banten, sebesar 72,9\% adalah peserta KB aktif. Suntik adalah jenis alat KB yang paling banyak digunakan yaitu sebesar $51,06 \%$ dan pil sebesar $25,04 \%$ (Kementerian Kesehatan RI, 2018).

Perilaku pemilihan metode kontrasepsi oleh wanita akseptor $\mathrm{KB}$ sangat mempengaruhi penggunan metode kontrasepsi $\mathrm{KB}$ di Indonesia. Perilaku tersebut dipengaruhi oleh beberapa faktor. Notoatmodjo (2007) mengidentifikasi beberapa faktor yang mendukung pemanfaatan pelayanan kesehatan salah satunya pelayanan $\mathrm{KB}$ dengan metode kontrasepsi seperti faktor presdiposisi, faktor pemungkin/enabling, dan faktor (C) Poltekkes Kemenkes Jakarta I Jl. Wijaya Kusuma No. 47-48 Cilandak Jakarta Selatan, Indonesia email: jurnalquality@poltekkesjakarta1.ac.id penguat/reinforcing. Faktor prediposisi yaitu tingkat pendidikan, pengetahuan, umur, paritas dan sikap, faktor enabling yaitu kelengkapan fasilitas pelayanan $\mathrm{KB}$, pemberian informasi $\mathrm{KB}$, biaya penggunaan kontrasepsi, dan akses pelayanan $\mathrm{KB}$ serta faktor reinforcing yaitu dukungan suami.

Dampak yang diakibatkan oleh rendahnya proporsi peserta KB aktif MKJP dibandingkan Non MKJP diantaranya adalah mempengaruhi peningkatan angka kelahiran yang terdapat di Kabupaten Tangerang dan wilayah kerja Puskesmas Jalan Emas. Dapat dilihat dari kenaikan jumlah total kelahiran Kabupaten Tangerang pada tahun 2016 yaitu sebanyak 68.216 kelahiran menjadi 74.987 kelahiran pada tahun. Khususnya wilayah Puskesmas Jalan Emas jumlah kelahiran pada tahun 2016 sebanyak 1.079 kelahiran dan pada tahun 2018 mengalami kenaikan yaitu sebanyak 1.146 jumlah kelahiran (Dinas Kesehatan Kabupaten Tangerang, 2016 dan Dinas Kesehatan Kabupaten Tangerang, 2018). Masih rendahnya proporsi peserta KB aktif MKJP dibandingkan Non MKJP perlu untuk dikaji lebih lanjut untuk mengetahui faktor- faktor yang berhubungan dengan perilaku pemilihan metode kontrasepsi pada akseptor KB di Puskesmas Jalan Emas Kabupaten Tangerang tahun 2020.

\section{Metode}

Penelitian yang dilakukan merupakan penelitian deskriptif analitik dengan menggunakan desain penelitian cross sectional. Populasi penelitian ini adalah wanita akseptor KB di wilayah kerja Puskesmas Jalan Emas dengan pengambilan sampel sebanyak 330 responden. Pengambilan data dilakukan dengan cluster sampling dan proportionate random sampling dengan menggunakan kuesioner. Analisis data yang dilakukan analisis univariat dan analisis bivariat hubungan melalui uji chi square dengan taraf signifikasi 0,05 .

\section{Hasil}

Penelitian ini dilakukan di wilayah kerja Puskesmas Jalan Emas Kabupaten Tangerang pada bulan Januari 2021, hasil penelitian disajikan sebagai berikut

ISSN 2655-2434 
Analisis Univariat

Tabel 1. Distribusi Frekuensi

\begin{tabular}{ccc}
\hline Variabel & Frekuensi & $\begin{array}{c}\text { Persentase } \\
(\%)\end{array}$
\end{tabular}

\begin{tabular}{|c|c|c|}
\hline \multicolumn{3}{|l|}{ Alat Kontrasepsi } \\
\hline $\begin{array}{l}\text { Pil } \\
\text { Suntik } \\
\text { IUD } \\
\text { Implan } \\
\text { Tubektomi }\end{array}$ & $\begin{array}{c}82 \\
172 \\
54 \\
8 \\
14\end{array}$ & $\begin{array}{c}24,8 \\
52,1 \\
16,4 \\
2,4 \\
4,2\end{array}$ \\
\hline $\begin{array}{l}\text { Tingkat Pendidikan } \\
\text { Tidak Tamat SD } \\
\text { Tamat SD } \\
\text { Tamat SMP } \\
\text { Tamat SMA } \\
\text { Tamat D3 } \\
\text { Tamat S1 } \\
\text { Tamat S2 }\end{array}$ & $\begin{array}{c}9 \\
52 \\
70 \\
138 \\
22 \\
37 \\
2\end{array}$ & $\begin{array}{c}2,7 \\
15,8 \\
21,2 \\
41,8 \\
6,7 \\
11,2 \\
0,6\end{array}$ \\
\hline $\begin{array}{l}\text { Kurang } \\
\text { Cukup } \\
\text { Baik }\end{array}$ & $\begin{array}{c}48 \\
189 \\
93\end{array}$ & $\begin{array}{l}14,5 \\
57,3 \\
28,2\end{array}$ \\
\hline $\begin{array}{l}\text { Umur } \\
\qquad \begin{array}{l}\leq 35 \text { tahun } \\
>35 \text { tahun }\end{array}\end{array}$ & $\begin{array}{l}176 \\
154\end{array}$ & $\begin{array}{l}53,3 \\
46,7\end{array}$ \\
\hline $\begin{array}{l}\text { Paritas } \\
\qquad \begin{array}{l}\text { Primipara } \\
\text { Multipara } \\
\text { Grandemultipara }\end{array}\end{array}$ & $\begin{array}{c}61 \\
231 \\
38\end{array}$ & $\begin{array}{l}18,5 \\
70,0 \\
11,5\end{array}$ \\
\hline $\begin{array}{l}\text { Sikap } \\
\quad \text { Negatif } \\
\text { Positif } \\
\text { Paparan Informasi KB }\end{array}$ & $\begin{array}{l}198 \\
132\end{array}$ & $\begin{array}{l}60,0 \\
40,0\end{array}$ \\
\hline $\begin{array}{l}\text { Tidak Lengkap } \\
\text { Lengkap } \\
\text { Akses Pelayanan KB }\end{array}$ & $\begin{array}{l}118 \\
212\end{array}$ & $\begin{array}{l}35,8 \\
64,2\end{array}$ \\
\hline $\begin{array}{l}\text { Sulit } \\
\text { Mudah } \\
\text { Biava Penogunaan }\end{array}$ & $\begin{array}{l}126 \\
204\end{array}$ & $\begin{array}{l}38,2 \\
61,8\end{array}$ \\
\hline $\begin{array}{c}\text { Mahal } \\
\text { Tidak Mahal } \\
\text { Dukungan Suami }\end{array}$ & $\begin{array}{l}194 \\
136\end{array}$ & $\begin{array}{l}59,8 \\
41,2\end{array}$ \\
\hline $\begin{array}{l}\text { Tidak Mendukung } \\
\text { Mendukung }\end{array}$ & $\begin{array}{c}34 \\
296\end{array}$ & $\begin{array}{l}10,3 \\
89,7\end{array}$ \\
\hline
\end{tabular}

Sumber: data riset, 2021
Tabel 1 menunjukkan wanita akseptor KB lebih banyak yang memilih alat kontrasepsi suntik yaitu 172 wanita akseptor KB (52,1\%). Tingkat pendidikan wanita akseptor KB lebih besar memiliki tingkat pendidikan Tamat SMA yaitu 138 wanita akseptor KB (41,8\%).

Berdasrakan tingkat pengetahuan wanita akseptor KB lebih besar memiliki pengetahuan cukup tentang $\mathrm{KB}$ dan kontrasepsi yaitu sebanyak 189 wanita akseptor KB (57,3\%). Frekuensi wanita akseptor KB lebih banyak memiliki umur yaitu $\leq 35$ tahun yaitu 176 wanita akseptor $\mathrm{KB}(53,3 \%)$. Wanita akseptor KB lebih banyak memiliki paritas multipara (memiliki 2 sampai 3 orang anak) yaitu sebanyak 231 wanita akseptor KB (70,0\%). Berdasarkan sikap terhadap MKJP, wanita akseptor KB lebih banyak memiliki sikap negatif terhadap metode kontrasepsi MKJP yaitu sebanyak 198 wanita akseptor KB $(60,0 \%)$.

Distribusi frekuensi berdasarkan kelengkapan pelayanan $\mathrm{KB}$, wanita akseptor $\mathrm{KB}$ lebih besar memiliki kelengkapan pelayanan KB dengan kategori lengkap yaitu sebanyak 186 wanita akseptor KB (56,4\%). Paparan informasi, KB yang didapatkan wanita akseptor KB lebih besar yaitu memadai sebanyak 212 wanita akseptor KB $(64,2 \%)$.

Berdasarkan akses pelayanan $\mathrm{KB}$, wanita akseptor KB lebih besar memiliki akses pelayanan KB mudah yaitu sebanyak 204 wanita akseptor KB $(61,8 \%)$. Menurut biaya penggunaan kontrasepsi, wanita akseptor KB lebih besar menyatakan biaya penggunaan kotrasepsi mahal yaitu sebanyak 194 wanita akseptor KB $(59,8 \%)$.

Distribusi frekuensi berdasarkan dukungan suami secara umum mendukung yaitu sebanyak 296 wanita akseptor KB $(89,7 \%)$. 


\section{Analisis Bivariat}

Tabel 2. Hubungan Faktor Prediposisi dengan

Pemilihan Metode Kontrasepsi

\begin{tabular}{|c|c|c|}
\hline Metode & rasepsi & \\
\hline $\begin{array}{l}\text { Non } \\
\text { MK IP }\end{array}$ & MKJP & P. \\
\hline n $\%$ & $\%$ & value \\
\hline
\end{tabular}

$\% \mathrm{CI})$

\begin{tabular}{|c|c|c|c|c|c|c|}
\hline \multicolumn{7}{|l|}{ Pendidikan } \\
\hline Dasar & 114 & 87,0 & 17 & 13,0 & 0,000 & $\begin{array}{l}0,2 \\
(0,1-0,5)\end{array}$ \\
\hline Menengah & 101 & 73,2 & 37 & 26,8 & 0,250 & $\begin{array}{l}0,6 \\
(0,3-1,2)\end{array}$ \\
\hline Tinggi & 39 & 63,9 & 22 & 36,1 & & \\
\hline \multicolumn{7}{|l|}{ Pengetahuan } \\
\hline Kurang & 44 & 91,7 & 4 & 8,3 & 0,034 & $\begin{array}{l}0,2 \\
(0,1-0.8)\end{array}$ \\
\hline Cukup & 140 & 74,1 & 49 & 25,9 & 0,943 & $\begin{array}{l}1,0 \\
(0,6-1,8)\end{array}$ \\
\hline & 70 & \multicolumn{4}{|c|}{ Umur } & \\
\hline$\leq 35$ thn & 142 & 80,7 & 34 & 19,3 & 0,114 & $\begin{array}{l}1,5 \\
(0,9-2,6)\end{array}$ \\
\hline $\begin{array}{l}>35 \text { thn } \\
\text { Paritas }\end{array}$ & 112 & 72,7 & 42 & 27,3 & & \\
\hline Primipara & 50 & 82,0 & 11 & 18,0 & 0,191 & $\begin{array}{l}0,4 \\
(0,1-1,2)\end{array}$ \\
\hline Multipara & 178 & 77,1 & 53 & 22,9 & 0,343 & $\begin{array}{l}0,6 \\
(0,3-1,3)\end{array}$ \\
\hline $\begin{array}{l}\text { Grande } \\
\text { multipara } \\
\text { Sikan }\end{array}$ & 26 & 68,4 & 12 & 31,6 & & \\
\hline Negatif & 154 & 77,8 & 44 & 22,2 & 0,769 & $\begin{array}{l}1,1 \\
(0,6-1,8)\end{array}$ \\
\hline Positif & 100 & 75,8 & 32 & 24,2 & & \\
\hline
\end{tabular}

Sumber: data riset, 2021

Hasil uji hubungan variabel pendidikan dasar menunjukkan nilai $\mathrm{p}=0,000$ sehingga disimpulkan terdapat hubungan signifikan antara pendidikan dasar dan pemilihan metode kontrasepsi pada responden dan responden. Sedangkan pendidikan menengah memiliki nilai $\mathrm{p}=0,250$ yang diartikan bahwa tidak terdapat hubungan antara pendidikan menengah dengan pemilihan metode kontrasepsi. Nilai $\mathrm{OR}=0,2$ pada pendidikan dasar, artinya wanita akseptor KB dengan pendidikan dasar memiliki peluang 0,2 kali lebih besar memilih metode kontrasepsi Non MKJP yaitu pil dan suntik dibandingkan wanita akseptor $\mathrm{KB}$ dengan pendidikan tinggi dan nilai $\mathrm{OR}=0,6$ pada pendidikan

(C) Poltekkes Kemenkes Jakarta I

Jl. Wijaya Kusuma No. 47-48 Cilandak Jakarta Selatan, Indonesia email: jurnalquality@poltekkesjakarta1.ac.id menengah, dapat diartikan wanita akseptor $\mathrm{KB}$ dengan pendidikan menengah memilili peluang 0,6 kali lebih besar memilih metode kontrasepsi Non MKJP yaitu pil dan suntik dibandingkan wanita akseptor KB dengan pendidikan tinggi.

Hasil uji hubungan variabel pengetahuan kurang didapatkan nilai $\mathrm{p}=0,034$ sehingga disimpulkan terdapat hubungan signifikan antara pengetahuan kurang dengan pemilihan metode kontrasepsi pada responden. Sedangkan pengetahuan cukup menunjukkan nilai $\mathrm{p}$-value 0,943, dapat diartikan tidak terdapat hubungan antara pengetahuan cukup dengan pemilihan metode kontrasepsi. Didapatkan pula $\mathrm{OR}=0,2$ pada pengetahuan kurang, artinya wanita akseptor $\mathrm{KB}$ dengan pengetahuan kurang memiliki peluang 0,2 kali lebih besar untuk memilih metode Non MKJP daripada wanita akseptor KB yang memiliki tingkat pengetahuan baik dan nilai $\mathrm{OR}=1,0$ pada pengetahuan cukup, dapat diartikan wanita akseptor KB yang memiliki pengetahuan cukup berpeluang 1,0 kali lebih besar untuk memilih metode kontrasepsi Non MKJP daripada responden dengan pengetahuan baik.

Hasil uji hubungan pada variabel umur dan pemilihan metode kontraepsi yaitu menunjukkan nilai p-value sebesar 0,114 , maka dapat diartikan tidak terdapat hubungan umur dengan pemilihan metode kontrasepsi pada wanita akseptor KB. Hasil analisis diperoleh nilai $\mathrm{OR}=1,5$, artinya pada wanita akseptor $\mathrm{KB}$ yang berumur $\leq 35$ tahun memiliki peluang lebih 1,5 kali untuk memilih metode kontrasepsi Non MKJP dibandingkan wanita akseptor KB yang berumur $>35$ tahun.

Uji hubungan pada variabel paritas menunjukkan $\mathrm{p}$-value $=0,191$ sehingga dapat disimpulkan tidak terdapat hubungan antara paritas primipara dengan pemilihan metode kontrasepsi dan pada wanita akseptor multipara menunjukkan nilai p-value $=0,343$ yang disimpulkan tidak terdapat hubungan paritas multipara dan pemilihan metode kontrasepsi. Didapatkan pula nilai $\mathrm{OR}=0,4$ pada primipara, artinya responden primipara memiliki peluang 0,4 kali lebih besar untuk memiliki Non MKJP daripada responden grandemultipara dan nilai $\mathrm{OR}=0,6$ pada multipara, dapat diartikan wanita akseptor KB multipara peluang 0,6 kali lebih besar memilih metode kontrasepsi Non MKJP dibandingkan wanita akseptor KB grandemultipara.

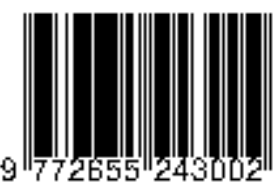


Pada variabel sikap, nilai $\mathrm{p}=0,769$ menunjukkan bahwa tidak ada hubungan antara sikap wanita akseptor $\mathrm{KB}$ dengan pemilihan metode kotrasepsi wanita akseptor KB. Hasil analisis diperoleh nilai $\mathrm{OR}=1,1$, artinya pada wanita akseptor KB yang memiliki sikap negatif $1,1 \mathrm{kali}$ lebih berpeluang memilih metode kontrasepsi Non MKJP dibandingkan wanita akseptor KB yang memiliki sikap positif.

Tabel 3. Hubungan Faktor Pemungkin dengan Pemilihan Metode Kontrasepsi

\begin{tabular}{|c|c|c|c|c|}
\hline \multicolumn{3}{|c|}{ Metode Kontrasepsi } & \multirow{3}{*}{$\begin{array}{c}\text { P- } \\
\text { value }\end{array}$} & \multirow{3}{*}{$\begin{array}{l}\text { OR } \\
(95\end{array}$} \\
\hline Non & & & & \\
\hline n $\%$ & $\mathbf{n}$ & $\%$ & & \\
\hline
\end{tabular}

\begin{tabular}{|c|c|c|c|c|c|c|}
\hline \multicolumn{7}{|l|}{ Kelayakan } \\
\hline KB & & & & & \multirow[b]{3}{*}{0,001} & \multirow{3}{*}{$\begin{array}{c}2,6 \\
(1,5-4,7)\end{array}$} \\
\hline Tidak & 124 & 86,1 & 20 & 13,9 & & \\
\hline $\begin{array}{l}\text { Lengkap } \\
\text { Lengkap }\end{array}$ & 130 & 69,9 & 56 & 30,1 & & \\
\hline \multicolumn{7}{|l|}{ Paparan } \\
\hline \multicolumn{7}{|l|}{ Informasi } \\
\hline Tidak & 99 & 83,9 & 19 & 16,1 & \multirow{3}{*}{0,036} & \multirow{3}{*}{$\begin{array}{c}1,9 \\
(1,0-3,4)\end{array}$} \\
\hline $\begin{array}{l}\text { Memadai } \\
\text { Memadai }\end{array}$ & 155 & 73,1 & 57 & 26,9 & & \\
\hline Akses & & & & & & \\
\hline \multicolumn{7}{|l|}{ Pelayanan } \\
\hline Sulit & 106 & 84,1 & 20 & 15,9 & \multirow{2}{*}{0,022} & \multirow{2}{*}{$\begin{array}{c}2,0 \\
(1,1-3,5)\end{array}$} \\
\hline Mudah & 148 & 72,5 & 56 & 27,5 & & \\
\hline \multicolumn{7}{|l|}{ Biaya } \\
\hline \multicolumn{7}{|l|}{ Kontrasepsi } \\
\hline Mahal & 43 & 80,7 & 21 & 19,3 & & 0,5 \\
\hline Tidak Mahal & 211 & 72,7 & 55 & 27,3 & 0,057 & $(0,2-0,9)$ \\
\hline
\end{tabular}

Sumber: data riset, 2021

Hasil penelitian menunjukkan bahwa P-value dari hasil uji statistik dengan variabel kelengkapan pelayanan KB 0,001 yang berarti ada hubungan signifikan antara kelengkapan pelayanan KB dengan penggunaan metode kontrasepsi pada wanita akseptor KB. Hasil analisis diperoleh nilai $\mathrm{OR}=2,6$ artinya pada wanita akseptor $\mathrm{KB}$ dengan kelengkapan pelayanan KB tidak lengkap 2,6 kali lebih berpeluang memilih metode kontrasepsi Non

(C) Poltekkes Kemenkes Jakarta I

Jl. Wijaya Kusuma No. 47-48 Cilandak Jakarta Selatan, Indonesia email: jurnalquality@poltekkesjakarta1.ac.id
MKJP dibandingkan wanita akseptor KB dengan kelengkapan pelayanan KB lengkap.

Hasil penelitian menunjukkan bahwa $\mathrm{P}$-value dari hasil uji statistik dengan variabel paparan informasi $\mathrm{KB}$ adalah 0,036 berarti ada hubungan signifikan antara paparan informasi $\mathrm{KB}$ dengan pemilihan metode kontrasepsi pada wanita akseptor KB. Kemudian nilai $\mathrm{OR}=1,9$ berarti pada wanita akseptor $\mathrm{KB}$ dengan paparan informasi $\mathrm{KB}$ tidak memadai 1,9 kali lebih berpeluang memilih metode Non MKJP daripada wanita akseptor KB dengan paparan informasi memadai.

Pada variabel akses pelayanan KB didapatkan nilai p-value sebesar 0,022 yang berarti ada hubungan signifikan antara akses pelayanan KB dengan pemilihan metode kontrasepsi responden. Sedangkan nilai $\mathrm{OR}=2,0$ diartikan bahwa pada responden dengan akses pelayanan KB sulit 2,0 kali lebih berpeluang memilih metode kontrasepsi Non MKJP dibandingkan dengan akses pelayanan $\mathrm{KB}$ mudah.

Nilai p-value dari hasil uji hubungan biaya penggunaan adalah 0,057 sehingga disimpulkan bahwa tidak terdapat hubungan biaya penggunaan kontrasepsi dengan pemilihan metode kontrasepsi pada wanita akseptor KB.

Tabel 4. Hubungan Faktor Penguat dengan Pemilihan Metode Kontrasepsi

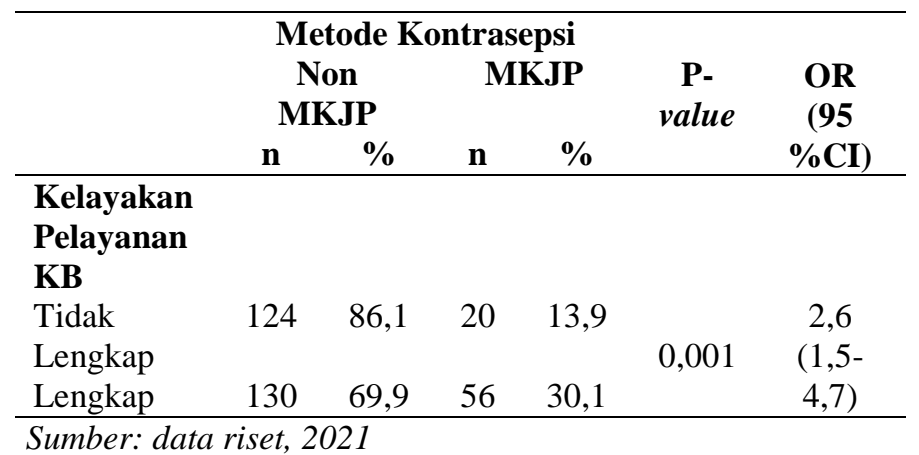

Variabel dukungan suami memiliki p-value sebesar 0,993, sehingga disimpulkan tidak terdapat hubungan signifikan antara dukungan suami dengan pemilihan metode kontrasepsi pada wanita akseptor KB. Hasil analisis diperoleh nilai $\mathrm{OR}=0,9$, artinya pada wanita akseptor KB dengan dukungan suami bepeluang 0,9 kali memilih metode kontrasepsi Non

ISSN 2655-2434

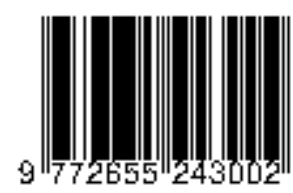


MKJP karena berdasarkan penelitian persentase dukungan suami relatif sama untuk masing-masing metode kontrasepsi.

\section{Pembahasan}

\section{A. Hubungan Tingkat Pendidikan dan Pemilihan Metode Kontrasepsi}

Terdapat hubungan yang signifikan antara tingkat pendidikan dasar dan pemilihan metode kontrasepsi pada wanita akseptor KB. Hasil penelitian sejalan dengan penelitian Siringoringo (2018) kepada ibu akseptor KB yang menunjukan hubungan yang signifikan antara faktor pendidikan dengan penggunaan kontrasepsi hormonal yaitu suntik dan pil.

Tingkat pendidikan yang tinggi pada wanita akseptor KB dapat meningkatkan seorang wanita untuk memiliki kemampuan literasi, memahami keadaan tubuh lebih baik serta mampu menyerap informasi, nilai, dan ide baru. Hal ini dapat mendorong keputusan wanita untuk memiliki jumlah anak yang lebih sedikit sehingga menggunakan metode kontrasepsi yang efektif. Sehingga tingkat pendidikan yang lebih rendah memungkinkan seseorang mengalami kesulitan mengambil keputusan memilih metode kontrasepsi jangka panjang dalam perencanaan keluarga (Olohiomeru, 2014).

Akan tetapi, hal ini berlainan dengan penelitian Basra \& Umur (2017) yang menunjukkan tidak terdapat hubungan signifikan pendidikan dengan pemilihan metode kontrasepsi hormonal yaitu pil dan suntik di wilayah kerja Puskesmas Lancirang Kabupaten Sidrap Tahun 2017.

\section{B. Hubungan Pengetahuan dengan Pemilihan Metode Kontrasepsi}

Terdapat hubungan yang signifikan antara faktor pengetahuan dengan pemilihan metode kontrasepsi pada wanita akseptor KB. Penelitian ini sesuai dengan penelitian yang dilakukan oleh Saragih \& Nugraheni (2018) pada akseptor KB (C) Poltekkes Kemenkes Jakarta I

J1. Wijaya Kusuma No. 47-48 Cilandak Jakarta Selatan, Indonesia email: jurnalquality@poltekkesjakarta1.ac.id menunjukkan ada hubungan signifikan antara faktor tingkat pengetahuan akseptor dengan pemilihan kontrasepsi non IUD.

Pengetahuan wanita akseptor KB yang kurang terkait $\mathrm{KB}$ dan kontrasepsi mempengaruhi wanita akseptor KB memilih metode kontrasepsi Non MKJP dibandingkan MKJP. Hal ini didukung oleh pemahaman bahwa semakin baik pengetahuan wanita akseptor $\mathrm{KB}$, maka akan meningkatkan kesadaran untuk menggunakan MKJP (Mahmudah \& Indrawati, 2015). Karena pendidikan dan pengetahuan terkait kontrasepsi yang dimiliki akseptor KB mampu meningkatkan pemahamannya untuk membuat keputusan sehingga memilih kontrasepsi dengan tingkat yang lebih efektif (Pazol et al., 2015).

Namun, penelitian yang dilakukan Revina, dkk (2018) tidak sesuai dengan hasil penelitian ini. Penelitian tersebut menunjukkan bahwa tidak terdapat hubungan yang signifikan antara pengetahuan dengan pe milihan kontrasepsi suntik pada akseptor KB.

\section{Hubungan antara Umur dan Pemilihan Metode Kontrasepsi}

Penelitian ini menunjukkan adanya hubungan signifikan antara umur dengan keputusan pemilihan metode kontrasepsi pada wanita akseptor KB. Sejalan dengan penelitian ini, penelitain yang dilakukan oleh Anggraeni \& Supeni (2019) pada wanita usia subur juga menyatakan umur tidak berhubungan dengan pemilihan kontrasepsi baik MKJP maupun Non MKJP.

Menurut Laurensia \& Mustikawati (2019), umur bukan merupakan faktor utama dalam keputusan memilih metode kontrasepsi hal ini karena bayak faktor lain seperti kebutuhan akseptor KB untuk menjarakkan kehamilan atau bahkan menambah kelahiran anak. Wanita akseptor KB di umur muda atau pun tua dapat memilih metode kontrasepsi sesuai kebutuhan. Berdasarkan hasil penelitian yang dilakukan, wanita akseptor KB berumur diatas 35 tahun masih banyak yang belum

ISSN 2655-2434 
menggunakan MKJP. Pada akseptor KB dengan umur lebih dari 30 tahun cenderung menginginkan penghentian kehamilan sehingga umumnya akan cendeerung menggunakan metode MKJP (Abubakar, 2014).

Penelitian lain yang tidak sejalan yaitu penelitian yang dilakukan oleh Ilmiyah, dkk (2018) pada wanita di Boyolali Jawa Tengah tentang determinan pemilihan metode IUD dan Implan yang menyimpulkan terdapat pengaruh yang positif antara wanita berumur $>35$ tahun dengan penggunaan kontrasepsi IUD dan Implan di Boyolali.

\section{Hubungan Paritas dengan Pemilihan Metode Kontrasepsi}

Hasil penelitian menyimpulkan tidak terdapat hubungan antara paritas wanita akseptor KB dengan penggunaan metode kontrasepsi. Berdasarkan penelitian ini juga didapatkan paritas sebagian besar wanita akseptor $\mathrm{KB}$ adalah multipara yaitu wanita akseptor KB sudah hamil dan atau melahirkan sebanyak 2-3 kali. Penelitian ini berkaitan dengan penelitian Mahmudah \& Indrawati (2015) pada akseptor KB wanita yang menyatakan paritas tidak memiliki hubungan dengan pemilihan MKJP.

Akan tetapi, hasil penelitian ini berlainan dengan pendapat bahwa jumlah anak yang dimiliki dapat mempengaruhi keputusan dalam memilih metode kontrasepsi pada akseptor KB. Jika seseorang memiliki lebih banyak jumlah anak , terdapat kecenderungan untuk tidak menginginkan menambah anak. Wanita yang merasa memiliki jumlah anak yang sesuai keiginan mereka akan cenderung memilih metode kontrasepsi jangka panjang untuk menghindari terjadinya kehamilan (Teferra \& Wondifraw, 2015).

Hasil penelitian berlawanan dengan penelitian Hutagalung (2018) terhadap Pasangan Usia Subur (PUS) yang secara statistik menunjukkan terdapat hubungan signifikan antara paritas PUS dengan keputusan memilih metode kontrasepsi.

\section{E. Hubungan antara Sikap dengan Pemilihan Metode Kontrasepsi}

Hasil penelitian menunjukkan bahwa dalam penelitian ini faktor sikap wanita wanita akseptor KB bukan merupakan faktor yang berhubungan dengan pemilihan metode kontrsepsi. Penelitian lain yang sejalan adalah penelitian Amir (2017) yang menunjukan sikap tidak berhubungan dengan keputusan Pasangan Usia Subur untuk memilih alat kontrasepsi.

Sikap positif dari akseptor KB diperlukan untuk menentukan pemilihan metode kontrasepsi yang sesuai dengan keinginannya berdasarkan hasil pengetahuan dan perasaannya terhadap suatu metode kontrasepsi. Sikap didapatkan dari proses pembelajaran dan keadaan sosial budaya masyarakat di lingkungan sekitar. Sikap terhadap metode kontrasepsi bisa didapatkan melalui pendidikan atau pengalaman wanita akseptor KB terutama pengalaman melahirkan (P, N, \& M, 2018). Meskipun akseptor KB mmemiliki pengetahuan tinggi, sikap merupakan faktor penting yang menyebabkan akseptor KB memilih metode kontrasepsi suntik (Revina et al., 2018)

Akan tetapi, penelitian yang dilakukan Hadie, et.al (2015) tidak menunjukkan hal yang sama. Penelitian tersebut menunjukan terdapat hubungan antara sikap terhadap MKJP dengan penggunaan MKJP pada akseptor KB di Kabupaten Sidoarjo.

\section{F. Hubungan Kelengkapan Pelayanan KB dengan Pemilihan Metode Kontrasepsi}

Terdapat hubungan yang signifikan antara kelengkapan pelayanan KB yang didapatkan responden dengan pemilihan metode kontrasepsi. Penelitian ini sesuai dengan penelitian Wulandari, dkk (2016) pada Pasangan Usia Subur di Kabupaten Sambas. Secara statistik penelitian tersebut menyimpulkan adanya hubungan antara kelengkapan pelayanan dengan partisipasi penggunaan MKJP. 
Menurut Fienalia, ketersediaan atau kelengkapan pelayanan KB mempengaruhi keputusan pemilihan dan penggunaan metode kontrasepsi jangka panjang (MKJP) (Fienalia, 2012). Hal ini sesuai dengan teori bahwa kelengkapan pelayanan $\mathrm{KB}$ dapat terlihat dari terpenuhinya semua alur pelayanan KB utamanya di faskes tingkat pertama dan jejaringnya, hal ini dapat mendukung kemudahan akseptor $\mathrm{KB}$ untuk mendapatkan pelayanan KB yang sesuai dan tepat (Kementrian Kesehatan Republik Indonesia, 2014).

Akan tetapi, berlainan dengan hasil penelitian ini, penelitian Masruroh \& Laili (2018) pada Ibu Nifas di BPM Bashori Surabaya secara statistik menunjukkan tidak ada pengaruh antara kelengkapan pelayanan dengan pemilihan MKJP.

\section{G. Hubungan Paparan Informasi KB dengan Pemilihan Metode Kontrasepsi}

Kesimpulan penelitian menunjukkan adanya hubungan yang signifikan antara paparan informasi yang diterima oleh responden dengan pemilihan metode kontrasepsi. Hasil penelitian ini berkaitan dengan penelitian Syukaisih (2011) yang menunjukkan adanya hubungan yang signifikan antara pemberian informasi oleh tenaga kesehatan terhadap pemilihan kontrasepsi akseptor KB aktif.

Informasi memadai mengenai metode kontrasepsi yang didapatkan wanita akseptor $\mathrm{KB}$ untuk membuat pilihan metode kontrasepsi termasuk informasi perbandingan jenis metode kontrasepsi, kelebihan dan kekurangan serta manfaat dan dampak kontrasepsi tersebut bagi kesehatan (World Health Organization, 2014). Oleh karena itu, dibutuhkan paparan informasi yang lengkap terkait $\mathrm{KB}$ dan metode kontrasepsi agar akseptor KB dapat memutuskan pemilihan metode kontrasepsi yang tepat dan sesuai kebutuhannya (Budihartini dkk, 2020).

Namun, hal ini tidak sejalan dengan penelitian Budihartini et al., (2020) yang menyatakan bahwa paparan informasi yang didapatkan akseptor KB tidak berhubungan dengan penggunaan MKJP.

(C) Poltekkes Kemenkes Jakarta I

J1. Wijaya Kusuma No. 47-48 Cilandak Jakarta Selatan, Indonesia email: jurnalquality@poltekkesjakarta1.ac.id

\section{H. Hubungan Akses Pelayanan KB dengan Pemilihan Metode Kontrasepsi}

Hasil penelitian menyimpulkan adanya hubungan yang signifikan antara akses pelayanan yang dimiliki oleh responden dengan pemilihan metode kontrasepsi. Penelitian sejalan dengan penelitian Yuanti (2019) yang menunjukkan adanya hubungan yang signifikan antara akses pelayanan KB dengan pemilihan MKJP Pasangan Usia Subur di Kecamatan Purwadadi. Penelitian ini juga sesuai dengan penelitian yang dilakukan oleh Hadie et al. (2015) yang menunjukkan bahwa sikap terhadap akses pelayanan KB memiliki hubungan dengan penggunaan MKJP.

Peningkatan penggunaan KB MKJP oleh masyarakat membutuhkan beberapa faktor terkait akses dan kualitas seperti meningkatkan jaminan pelayanan, meningkatkan dukungan serta membutuhkan peningkatan pengetahuan dan akseptabilitas oleh masyarakat agar meningkatnya akses, kualitas serta kesertaraan terhadap metode MKJP (Purwoko, 2011). Akses menuju fasilitas pelayanan $\mathrm{KB}$ berpengaruh terhadap kemudahan dan kenyamanan akseptor KB mendapatkan pelayanan KB yang lengkap dan sesuai kebutuhan (Mi'rajiah dkk., 2019).

Akan tetapi, penelitian yang dilakukan Sujana (2015) pada akseptor KB di Wilayah Kerja Puskesmas Pundata Baji Kabupaten Pangkep tidak sejalan dengan hasil penelitian ini. Secara statistik hasil penelitian Sujana (2015) menyimpulkan bahwa akses pelayanan $\mathrm{KB}$ tidak berhubungan dengan pemilihan kontrasepsi pada akseptor KB.

\section{Hubungan Biaya Penggunaan dengan Pemilihan Metode Kontrasepsi \\ Kesimpulan penelitian menunjukkan tidak} terdapat hubungan signifikan biaya penggunaan kontrasepsi yang dikeluarkan oleh responden dengan pemilihan metode kontrasepsi. Penelitian ini sejalan dengan penelitian yang dilakukan oleh Masruroh \& Laili (2018) pada Ibu Nifas di BPM

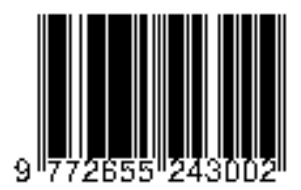


Bashori Surabaya yang menunjukkan biaya tidak memiliki pengaruh signifikan dengan pemilihan kontrasepsi MKJP.

Biaya penggunaan metode kontrasepsi dapat dipengaruhi oleh adanya pemberian manfaat semua biaya pelayanan KB mulai dari konseling hingga pemasangan alat kontrasepsi dibiayai BPJS Kesehatan apabila sesuai dengan prosedur dan indikasi medis di fasilitas kesehatan KB tertentu utamanya fasilitas kesehatan milik pemerintah (BPJS Kesehatan, 2016). Penggantian metode kontrasepsi pada wanita akseptor KB didukung persepsi wanita akseptor KB mendukung penggunaan pelayanan berkualitas tinggi pada fasilitas pelayanan KB swasta dengan metode yang sesuai kebutuhan dan kenyamanan wanita akseptor KB lebih diminati meskipun wanita akseptor KB harus membayar biaya yang lebih besar dibandingkan di pelayanan KB pemerintah (Amran et al., 2019).

Akan tetapi, penelitian yang dilakukan Septalia \& Puspitasari (2016) pada akseptor KB tidak sejalan dengan penelitian ini. Secara statistik penelitian tersebut menunjukkan biaya penggunaan berpengaruh signifikan terhadap pemilihan metode kontrasepsi.

\section{J. Hubungan antara Dukungan Suami dengan Pemilihan Metode Kontrasepsi}

Hasil penelitian menyimpulkan bahwa tidak terdapat hubungan signifikan antara dukungan suami yang didapatkan wanita akseptor KB dengan pemilihan metode kontrasepsi. Penelitian ini sejalan dengan penelitian Yuanti (2019) yang menyatakan bahwa dukungan suami tidak berhubungan signifikan dengan keputusan memilih MKJP.

Beberapa suami merasa bahwa diskusi dan kesepakatan antara suami dan istri tidak selalu berpengaruh terhadap keputusan memilih kontrasepsi jika wanita subur sudah memutuskan untuk menggunakannya. Begitu pula jika sudah ada diskusi sebelumnya, suami menganggap lebih mudah apabila penggunaan metode kontrasepsi

(C) Poltekkes Kemenkes Jakarta I

Jl. Wijaya Kusuma No. 47-48 Cilandak Jakarta Selatan, Indonesia email: jurnalquality@poltekkesjakarta1.ac.id ditentukan dan menjadi tanggung jawab wanita akseptor KB sebagai pengguna (Capova, 2014).

Namun penelitian ini tidak sejalan dengan pernyataan bahwa banyak wanita di beberapa kelompok masyarakat yang membutuhkan dan mengandalkan suami dalam mengambil keputusan penting termasuk pelayanan kesehatan keluarga karena memiliki anggapan suami adalah pengambil keputusan utama (Durowade et al., 2017). Suami juga dianggap penting dalam pemilihan metode kontraepsi berkaitan dengan dukungan keuangan dalam biaya penggunaan metode kontrasepsi wanita akseptor KB (Capova, 2014). Selain itu, penelitian Mahmudah \& Indrawati (2015) juga tidak sejalan dengan penelitian ini. Penelitian tersebut menyatakan dukungan suami pada akseptor KB wanita berhubungan signifikan dengan pemilihan MKJP.

\section{Kesimpulan dan Saran}

Pada faktor prediposisi/prediposing ada hubungan signifikan antara tingkat pendidikan dasar dan pengetahuan kurang dengan pemilihan metode kontrasepsi wanita akseptor $\mathrm{KB}$ di wilayah kerja Puskesmas Jalan Emas. Pada faktor pemungkin/enabling ada hubungan signifikan antara kelengkapan fasilitas pelayanan $\mathrm{KB}$, paparan informasi $\mathrm{KB}$, dan akses pelayanan $\mathrm{KB}$ dengan pemilihan metode kontrasepsi wanita akseptor KB di wilayah kerja Puskesmas Jalan Emas. Tidak ada hubungan yang signifikan pada faktor penguat/reinforcing yaitu dukungan suami dengan pemilihan metode kontrasepsi wanita akseptor KB di wilayah kerja Puskesmas Jalan Emas.

Akseptor KB diharapkan mampu meningkatkan pengetahuan dan mencari informasi dari tenaga kesehatan setempat terkait $\mathrm{KB}$ dan kontrsepsi. Serta diharapkan puskesmas dapat menyediakan kegiatan edukasi lengkap seputar sehingga wanita akseptor KB dapat lebih memahami

ISSN 2655-2434

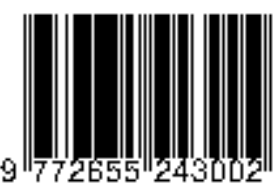


seputar KB dan efektifitas metode kontrasepsi jangka panjang (MKJP).

\section{Daftar Pustaka}

Abubakar, S. (2014). Kesehatan Reproduksi Dan Keluarga berencana Dalam Tanya Jawab. Jakarta: Raja Grafindo Persada.

Amir, F. (2017). Faktor-Faktor yang Berhubungan dengan Pemilihan Alat Kontrasepsi pada Pasangan Usia Subur ( PUS ) di Puskesmas Minasaupa Makassar Tahun 2017. Jurnal Kesehatan Delima Pelamonia, 1(2), 123-128.

Amran, Y., Nasir, N. M., Dachlia, D., Yelda, F., Utomo, B., Ariawan, I., \& Damayanti, R. (2019). Perceptions of Contraception and Patterns of Switching Contraceptive Methods Among Family-planning Acceptors in West Nusa Tenggara, Indonesia. Journal of Preventive Medicine and Public Health, 52(4), 258-264.

https://doi.org/10.3961/jpmph.18.198

Anggraeni, L., \& Supeni, S. (2019). Relation of Education, Age, and Parity To The Choice of Long- Acting and Permanent Methods (Lamps) And Non Lamps. Indonesian Journal of Nursing and Midwifery, 7(2), 105-110.

Badan Kependudukan dan Keluarga Berencana Nasional. (2018). Mengapa KB MKJP Penting? Jurnal Keluarga - Informasi Kependudukan, KB, Dan Pembangunan Keluarga, 7(Gerakan Lawan AIDS), 15-20.

Basra, \& Umur, S. F. (2017). Faktor- Faktor Yang Berhubungan Dengan Metode Kontrasepsi Jangka Pendek (Hormonal). Jurnal Ilmmiah Kesehatan Pencerah, 6(1), 7-14.

BKKBN. (2017). Peraturan Kepala Badan Kependudukan dan Keluarga Berencana Nasional Nomor 24 Tahun 2017 Tentang Pelayanan Keluarga Berencana Pasca Persalinan dan Pasca Keguguran. Pelayanan Keluarga Berencana Pasca Persalinan Dan Keguguran, 1(1), 64.

BPJS Kesehatan. (2016). Ini Strategi Kepatuhan dan Pemantapan Layanan BPJS Kesehatan 2016. Info BPJS Kesehatan, (33), 12.

Budihartini, E. M. S., Khusniyati, E., Purwati, H., \&

(C) Poltekkes Kemenkes Jakarta I

Jl. Wijaya Kusuma No. 47-48 Cilandak Jakarta Selatan, Indonesia email: jurnalquality@poltekkesjakarta1.ac.id
Yanti, A. D. (2020). Pemilihan Metode Kontrasepsi Pada Ibu Pasca Bersalin Berdasarkan Media Informasi yang Digunakan Dalam Konseling. Jurnal Keperawatan Dan Kebidanan. Retrieved from https://www.researchgate.net/publication/342 600901\%0APemilihan

Capova, A. (2014). Factors influencing contraceptive choice: study focused on Czech men. International Journal of Reproduction, Contraception, Obstetrics and Gynecology, $3(4), \quad 880$. https://doi.org/10.5455/23201770.ijrcog20141202

Dinas Kesehatan Kabupaten Tangerang. (2016). Profil Kesehatan Kabupaten Tangerang 2016 (p. 296). p. 296. Kabupaten Tangerang: Tim Penyusun.

Dinas Kesehatan Kabupaten Tangerang. (2018). Profil Kesehatan Kabupaten Tangerang Tahun 2018. Kabupaten Tangerang.

Dinas Kesehatan Provinsi Banten. (2019). Profil Kesehatan Provinsi Banten 2019.

Durowade, K. A., Omokanye, L. O., Elegbede, O. E., Adetokunbo, S., Olomofe, C. O., Ajiboye, A. D., ... Sanni, T. A. (2017). Barriers to Contraceptive Uptake among Women of Reproductive Age in a Semi-Urban Community of Ekiti State, Southwest Nigeria. Ethiopian Journal of Health Sciences, 27(2), 121-128. https://doi.org/10.4314/ejhs.v27i2.4

Fienalia, R. A. (2012). Faktor-Faktor Yang Berhubungan Dengan Penggunaan Metode Kontrasepsi Jangka Panjang (MKJP) Di Wilayah Kerja Puskesmas Pancoran Mas Kota Depok Tahun 2011. Universitas Indonesia.

Hadie, D. A., Kartasurya, M. I., \& Purnami, C. T. (2015). Beberapa Faktor yang Berhubungan dengan Penggunaan Metoda Kontrasepsi Jangka Panjang ( Studi pada Akseptor KB di Kabupaten Sidoarjo Provinsi Jawa Timur ). Jurnal Manajemen Kesehatan Indonesia, 03(01).

Hutagalung, S. P. (2018). Faktor- Faktor Yang Berhubungan Dengan Pemilihan Alat Kontrasepsi Oleh PUS di Puskesmas Rawang Pasar IV Kabupaten Asahan Tahun 2017. Politeknik Kesehatan Kemenkes Medan.

Ilmiyah, D. E., Budihastuti, U. R., Nurhaeni, I. D. A., \& Mudigdo, A. (2018). Determinants of ISSN 2655-2434

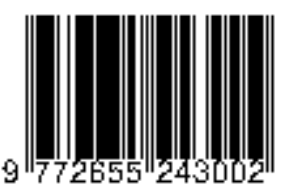


Women's Choice of a Long-Acting Reversible Contraceptive in Boyolali, Central Java. Journal of Maternal and Child Health, 03(03), 225-232.

https://doi.org/10.26911/thejmch.2018.03.03. 07

Kementerian Kesehatan RI. (2018). Riset Kesehatan Dasar 2018 (p. 614). p. 614. Jakarta.

Kementrian Kesehatan Republik Indonesia. (2014). Pedoman Manajemen Pelayanan Keluarga Berencana (2014th ed.). Jakarta: Kementerian Kesehatan.

Laurensia, L., \& Mustikawati, I. S. (2019). FaktorFaktor yang Berhubungan dengan Penggunaan Metode Kontrasepsi Jangka Panjang (MKJP). Helath Publika, 1 .

Mahmudah, L. T. N., \& Indrawati, F. (2015). Analisis Faktor Yang Berhubungan Dengan Pemilihan Metode Kontrasepsi Jangka Panjang (MKJP) Pada Akseptor KB Wanita Di Kecamatan Banyubiru Kabupaten Semarang. Unnes Journal of Public Health, 4(3), 76-85. https://doi.org/10.15294/ujph.v4i3.7222

Masruroh, N., \& Laili, U. (2018). Analisis Faktor yang Mempengaruhi pemilihan Metode Kontrasepsi Jangka Panjang pada Ibu Nifas di BPM Bashori Surabaya. Jurnal Kesehatan AlIrsyad, XI(2), 1-9.

Mi'rajiah, N., Noor, M. S., \& Arifin, S. (2019). Hubungan Dukungan Tenaga Kesehatan Dan Akses Ke Puskesmas Terhadap Pemakaian Metode Kontrasepsi Jangka Panjang. Homeostasis, 2(1), 113-120. Retrieved from https://ppjp.ulm.ac.id/journals/index.php

Olohiomeru, I. G. (2014). Is Education the best Contraceptive? International Journal of Education and Research, 2(7). Retrieved from https://www.ijern.com/

P, T., N, P., \& M, S. (2018). Knowledge, Attitude and Practices of Contraception among the Married Women of Reproductive Age Group in Selected Wards of Dharan Sub-Metropolitan City. Journal of Contraceptive Studies, 03(03), 1-8. $\quad$ https://doi.org/10.21767/24719749.100051

Pazol, K., Zapata, L. B., Tregear, S. J., MautoneSmith, N., Gavin, L. E., \& 1Division. (2015). Impact of Contraceptive Education on Contraceptive Knowledge and Decision

(C) Poltekkes Kemenkes Jakarta I

Jl. Wijaya Kusuma No. 47-48 Cilandak Jakarta Selatan, Indonesia email: jurnalquality@poltekkesjakarta1.ac.id
Making: A Systematic Review. Physiology \& Behavior, 49(201), S46-S56. https://doi.org/10.1016/j.amepre.2015.03.031. Impact

Purwoko, E. (2011). Kebijakan Penggunaan Metode Kontrasepsi Jangka Panjang (MKJP) dalam Jampersal. Forum Nasional II: Jaringan Kebijakan Kesehatan Indonesia. Makasar: KebijakanKesehatanIndonesia.net. Retrieved from kebijakankesehatanindonesia.net

Revina, Sakung, J., \& Amalinda, F. (2018). Hubungan Pengetahuan dan Dukungan Suami dengan Pemilihan Kontrasepsi Suntik pada Akseptor KB di Kelurahan Panasakan Kecamatan Baolan Kabupaten Tolitoli. Jurnal Kolaboratif Sains, 1(1), 1052-1063. Retrieved from http://jurnal.unismuhpalu.ac.id

Saragih, I. M., \& Nugraheni, A. (2018). FaktorFaktor Yang Berhubungan Dengan Pemilihan Penggunaan Metode Kontrasepsi Non IUD Pada Akseptor KB Wanita Usia Subur di Kelurahan Bandarharjo Semarang Utara. Diponegoro Medical Journal (Jurnal Kedokteran Diponegoro), 7(2), 1236-1250.

Septalia, R., \& Puspitasari, N. (2016). Faktor yang Memengaruhi Pemilihan Metode Kontrasepsi. Jurnal Biometrika Dan Kependudukan, 5(2), 91-98.

Siringoringo, H. E. (2018). Faktor - Faktor Yang Berhubungan Dengan Penggunaan Alat Kontrasepsi Hormonal di Bidan Praktik Mandiri Choirul Mala Palembang Tahun 2017. Jurnal Ilmiah Multi Science Kesehatan, 8, 5160.

Sujana, S. B. (2015). Faktor yang Berpengaruh dengan Pemilihan Alat Kontrasepsi pada Akseptor KB di Wilayah Kerja Puskesmas Pundata Baji Kabupaten Pangkep (Universitas Hasanuddin). Universitas Hasanuddin. Retrieved from digilib.unhas.ac.id

Syukaisih. (2011). Faktor-Faktor yang Berhubungan dengan Pemilihan Kontrasepsi di Puskesmas Rambah Samo Kabupaten Rokan Hulu. Jurnal Kesehatan Komunitas, 3(1), 34-40.

Teferra, A. S., \& Wondifraw, A. A. (2015). Determinants of Long Acting Contraceptive Use among Reproductive Age Women in Ethiopia: Evidence from EDHS 2011. Science Journal of Public Health, 3(1), 143.

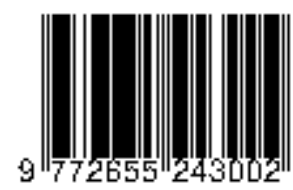


https://doi.org/10.11648/j.sjph.20150301.33

World Health Organization. (2014). Ensuring Human Rights in the Provision of Contraceptive Information and Services: Guidance and Recommendation.

Wulandari, Y., Taufik, M., \& Ridha, A. (2016). Faktor-Faktor Yang Mempengaruhi Penggunaan Metode Kontrasepsi JangkaPanjang (MKJP) Pada Pasangan Usia Subur di Kabupaten Sambas. Retrieved from http://repository.unmuhpnk.ac.id

Yuanti, Y. (2019). Determinan pemilihan Metode Kontrasepsi Jangka Panjang ( MKJP ) Pada pasangan Usia Subur/ Determinant Selection of Term Long-Term Contraception Methods in a Friendly Age Couple. Jurnal Ilmiah Ilmu Kesehatan: Wawasan Kesehatan, 5, 154-161. https://doi.org/10.33485/jiik-wk.v5i2.118 